\title{
The Influence of Earnings Quality and Liquidity on the Cost of Equity
}

\author{
Ming-Feng $\mathrm{Hsu}^{1} \&$ Jean $\mathrm{Yu}^{1}$ \\ ${ }^{1}$ Department of Banking and Finance, National Chiayi University, Chiayi, Taiwan \\ Correspondence: Jean Yu, Department of Banking and Finance, National Chiayi University, Chiayi City, 60054 \\ Taiwan. Tel: 886-5-273-2867. E-mail: jean@mail.ncyu.edu.tw
}

Received: February 2, 2015

Accepted: February 25, 2015

Online Published: March 25, 2015

doi:10.5539/ibr.v8n4p194

URL: http://dx.doi.org/10.5539/ibr.v8n4p194

\begin{abstract}
This study uses sample companies listed in Taiwan Stock Exchange and GreTai Securities Market during 2000 to 2011 to investigate the influence of earnings equality and liquidity on the cost of equity. We define discretionary accruals with three measures and real earnings management with three measures as indicators of earnings quality; trading volume, individual stock liquidity and market liquidity as liquidity measures and individual stock and market liquidity risk as liquidity risk measures. Panel data is suggested for this analysis. Firms manipulating discretionary accruals increase in the cost of equity, but ones operating real earnings management decrease in it when considering that the earnings quality and liquidity directly impact on it. The cost of equity is indirectly influenced by earnings quality and liquidity through information asymmetry measured by bid-ask spreads. The results show that no matter firms engaging in discretionary accruals or real earnings can decrease the cost of equity under higher levels of information asymmetry. The higher the trading volume or the individual stock liquidity risk, the lower the cost of equity when information asymmetry is low.
\end{abstract}

Keywords: earnings management, liquidity, cost of equity, information asymmetry

\section{Introduction}

The company cost of capital decided by manager decisions, asset valuation and financial reporting has become an important research topic, in particular the relationship between earnings quality and the cost of equity in the accounting field. Francis et al. (2004) present the accounting-based attributes significantly impact the cost of equity, especially on the quality of accruals. Bhattacharya et al. (2013) follow Francis et al. (2005) using an accruals-based measure as proxy for earnings quality, for the firms list on the New York Stock Exchange (NYSE) and NASDAQ to test the relationship between information asymmetry and earnings quality. The results show that poor earnings quality is highly correlated to information asymmetry, thus making the company costs of capital higher.

Numerous studies discuss the effects on different proxies of earnings quality on either equity or debt costs (see Botosan, 1997; Botosan \& Plumlee, 2002; Aboody et al., 2005; Francis et al., 2005). However, the results are inconclusive. The effects of associating factors interact more complex with the environment, measured at both the company and country level. Gray et al. (2009) analyze relations between accruals quality and cost of capital for Australian firms. They find significant positive relationship between earnings quality and the cost of equity. These findings are consistent with the empirical results of Francis et al. (2005). In this study, we test the relationship between accrual earnings quality and the cost of equity for Taiwan's listed companies and find the poor earnings quality is associated with higher cost of equity, consistent with the empirical results of Gray et al. (2009).

Information asymmetry embedding friction reduces volatility according to corporate financial management theory. Chae (2005) presents an inverse relationship between stock liquidity and information asymmetry before earnings announcements, but a positive relationship after the earnings announcement. Attig et al. (2006) find that greater deviation between excess control and ownership have a higher information asymmetry component in their bid-ask spread, suggesting poor disclosure quality deteriorates liquidity. But Kyle (1985) presents a model shows how a risk neutral and perfectly informed insider strategically profits from his private information and thus induce the liquidity. Deng and Ong (2014) test the manipulation effect of earnings management to the cost of equity for the Real Estate Investment Trusts (REITs). They find managers manipulate earnings management during the company's capital raising period to attract uninformed investors, thus increasing liquidity, thereby 
reducing the cost of equity.

Numerous studies explore the reasons for the stock liquidity, in particular the impact of liquidity on the required return of stock, which is the cost of capital. Capital Asset Pricing Model based on adjusted liquidity is another model to exam the effect of liquidity risk on the stock price or returns. Following Pastor and Stambaugh (2003), we calculate market liquidity risk, and apply discretionary accruals and real earnings management as a measure of earnings quality to analyzing the impact on the cost of equity. Our results are similar to what Deng and Ong (2014) find that the company managers use real earnings management to reduce the cost of equity.

Previous studies investigate the impact of earnings quality as information risk on the cost of equity, some other studies analyze the relationship among the individual liquidity, liquidity risk and capital costs. Most of the studies show that earnings quality and individual liquidity affect the cost of equity. Bhattacharya et al. (2012) use path analysis to exam the direct and indirect links between three measures of earnings quality and the cost of equity. They specify analytical models that specify both a direct link and an indirect link that is reconciled by information asymmetry consisting selection component of the bid-ask spread and PIN (the probability of informed trading). They find significant evidence of both a direct path from earnings quality and an indirect path from information asymmetry.

Following three-factor model of Fama-French (1993), we use abnormal returns as the cost of equity capital by collecting data from 2000 to 2011 in Taiwan to discuss a direct impact on cost of equity from earnings quality and liquidity of the shares, along with various levels of information asymmetry factor. Our contribution is twofold. First, the direct impact on equity of cost is prominent, the worse quality of discretionary accruals becomes and the higher trading volume becomes, the lower cost of equity is. Second, the higher the trading volume or the individual stock liquidity risk, the lower the cost of equity when information asymmetry is low.

The paper is organized as follows. Section I introduces the background and motivation. In section II, we discuss the hypothesis. Section III describes models, methodology and variables. Section IV presents empirical results and concludes.

\section{Hypothesis Design}

Previous studies show that the firms are less likely to do management earnings with higher transparency of financial reporting when accounting information are fully disclosure. Therefore, manager will selectively reveal financial information with asymmetric information as they rationally expect profit from engaging in earnings management.

Francis et al. (2004) examine seven earnings attributes which have distinguishable effects on firm-specific risk premium. Botosan and Plumlee (2002) find a positive association between cost of capital and voluntary timely disclosure. They show that relation between disclosure and cost of equity capital changes from a negative to a positive relation. Bhattacharya et al. (2012) present poor quality of earnings management that induces higher adverse selection risk and lower capital market liquidity. Therefore, investor requires higher risk premium and thus increase the cost of equity. Former chairman of the US Securities and Exchange Commission Levitt, A. said before that the most important benefits of the high-quality accounting standards are to improve liquidity and reduce the cost of capital for stock market.

We apply Fama and French (1993) three-factor model and follow modified Jones Model in Dechow et al. (1995) to estimating discretionary accruals as proxies in evaluating the quality of earnings management. As the corporate finance literature empirically states that information asymmetries reduce the liquidity of the company's securities and thus induce market frictions, Deng and Ong (2014) find firms with less liquid are very likely to manipulate earnings prior their equity offerings. Therefore, higher uninformed trading follows the real earnings management. Firms set the offer price at a smaller discount after engaging in real earnings management and stock returns decline in the long run.

We propose the following three hypotheses:

Hypothesis 1: When applying discretionary accruals as proxies in evaluating the quality of earnings management, poor quality management increases the cost of equity, and vice versa.

Few studies apply real earnings management as proxy to evaluating the company's earnings quality on the cost of equity capital by using REITs sample. When engaging in real earnings management, firms will increase liquidity, and reduce the cost of equity on increasing capital with cash. In this study, we define real earning management with three measures and impact on cost of equity.

Hypothesis 2: Uninformed traders do not have sufficient information when the company involves in real 
earnings management, so even with poor earnings quality, cost of equity still decreases.

The effect of liquidity fluctuations on asset prices increases the risk of individual investors with insufficient information. Investors will require a higher risk premium when liquidity risks increase, so as stock returns. In recent years, many researchers have begun to explore the relationship between stock market returns and liquidity with various proxies.

Chordia et al. (2001) show results of significantly negative cross-sectional relationship between stock returns and the variability of dollar trading volume, which is contrary to traditional hypothesis that risk-averse investors who will demand a higher risk premium, and then increase the company's costs of equity. On contrary, Acharya and Pedersen (2005) propose a stock's required return depends on its expected liquidity as well as on the covariances of its own return and liquidity with the market return. Moreover, low contemporaneous returns and high predicted future returns contribute to persistent negative shock. Therefore, the impact of liquidity on stock returns is inconclusive. Lee (2011) uses the liquidity-adjusted capital asset pricing model (LCAPM) of Acharya and Pedersen (2005) on investigating from 48 developed and emerging countries around the world. He finds that various liquidity risks arising from the covariances of asset return (liquidity) with local and global market liquidity (returns) are priced. However, liquidity risk also affected by the geographic, economic and political conditions, especially for the developing countries. Davivongs and Pavadutr (2012) also use the liquidity adjusted capital asset pricing model to investigate the liquidity risk of stocks in China and Taiwan. They find the evidence that systematic liquidity risk is more important than market risk in Taiwan. Therefore, we form hypothesis 3 as follows:

Hypothesis 3: The higher the liquidity, the lower the cost of equity. Therefore, the higher the liquidity risk, the higher the cost of equity.

\section{Research Model}

In order to examine the effect of earnings quality and liquidity on the cost of equity capital, a sample of 943 Taiwan-listed companies which excluding financial and insurance-related industries is collected covering year 2000 to 2011. The distribution of sample industry is shown in Table 1. There are 506 companies from electronics industry, about 54\% of all samples; followed by the building materials and chemical industries, 63 and 53 respectively, each accounting for about $6 \%$ of all samples. The rubber, electricity, gas and oil, and tourism industry, which have the least companies, are about $1 \%$ of the total number of samples. Daily stock trading volume and monthly financial information are collected from Taiwan Economic Journal (TEJ) database. The final data decrease to 135,428 after deducting incomplete data of 11,334 from 146,762 monthly data.

Table 1. The sample distribution of listed companies

\begin{tabular}{lcclcc}
\hline Industry & Number & Percent of sample & Industry & Number Percent of sample \\
\hline Food & 22 & 2.33 & Shipping \& Transportation & 23 & 2.44 \\
Plastic & 25 & 2.65 & Trading \& Consumers Goods & 16 & 1.70 \\
Textile & 48 & 5.09 & Building Material \& Construction & 63 & 6.68 \\
Electric Machinery & 48 & 5.09 & Tourism & 10 & 1.06 \\
Electronic Industry & 506 & 53.66 & Electrical \& Cable & 15 & 1.59 \\
Biotechnology \& Medical Care & 10 & 1.06 & Oil, Gas \& Electricity Industry & 10 & 1.06 \\
Chemical Industry & 53 & 5.62 & Others & 50 & 5.30 \\
Iron \& Steel & 35 & 3.71 & Total number & 943 & 100 \\
Rubber & 9 & 0.95 & & & \\
\hline
\end{tabular}

The paper uses individual stock abnormal returns measured by three-factor model which is proposed by Fama and French (1993) as the company's cost of capital. We specify the following regression model verification:

$$
\begin{gathered}
A R_{i, t}=\beta_{0}+\beta_{1} E_{i, t}+\beta_{2} \text { Volume }_{i, t}+\beta_{3} \text { LiRisk }_{i, t}+\beta_{4} \text { Liqui }_{i, t}+\beta_{5} \text { MLiRisk }_{t}+ \\
\beta_{6} \text { MLiqui }_{t}+\beta_{7} M K T_{t}+\beta_{8} S M B_{t}+\beta_{9} H M L_{t}+\beta_{10} \text { Markt }_{i}+\sum_{j} \lambda_{j} \text { Industry }_{i, j}
\end{gathered}
$$


where $A R_{i, t}$ is the abnormal returns for the stock $i$ in period $t$ measured by Fama-French three-factor model. $E M_{i, t}$ is earnings quality of firm $i$ in period $t$. The earnings quality is measured by the modified Jones model proposed by Dechow et al (1995), including abnormal total discretionary accruals (ATDA), abnormal discretionary current accruals (ADCA), and abnormal discretionary long-term accruals (ADLA) as a measure. Another way to measure earnings quality is real earnings management model proposed by Roychowdhury (2006), which includes abnormal cash flow from operation(ACFO), abnormal production costs (APC), abnormal discretionary expenses $(\mathrm{ADE})$, and integrated indicators $(\mathrm{CBPM}=\mathrm{APC}-\mathrm{ACFO}-\mathrm{ADE})$. Volume $_{i, t}\left(\right.$ PVolume $\left._{i, t}\right)$ is the total volume of stock trading (total transaction value of stock trading) divided by the total volume of outstanding shares (total transaction value of outstanding shares) of firm $i$ in period $t$. LiRisk $k_{i, t}$ is stock liquidity risk of firm $i$ in period t, and LiRisk $_{i, t}=\left(B A_{i, t}-m\left(B A_{i, t}\right)\right) / s\left(B A_{i, t}\right) . B A_{i, t}$ is the average monthly bid-ask spread. $m\left(B A_{i, t}\right)$ and $s\left(B A_{i, t}\right)$ are the mean and standard deviation, respectively. Liqui $_{i, t}$ is the liquidity of the stock of firm $i$ in period $t$, which is equal to the reciprocal of the bid-ask spread. MLiRisk $k_{t}$ is liquidity risk of the market in period $t$, MLiRisk $=\left(M \operatorname{Liqui}_{t}-m\left(M\right.\right.$ Liqui $\left.\left._{t}\right)\right) / s\left(M\right.$ Liqui $\left._{t}\right) . M$ Liqui $_{t}$ is market liquidity and $M$ Liqui $_{t}=\sum \gamma_{i, t} / \mathrm{N}, i=1 \ldots \mathrm{N} . m\left(\right.$ MLiqui $\left._{t}\right)$ and $\left(M_{L i q u i}\right)$ are the mean and standard deviation of MLiqui ${ }_{t}$, respectively. Market liquidity is estimated based on the method proposed by Pastor and Stambaugh (2003), the estimated equation is as follows.

$$
R_{i, d+1, t}^{e}=\theta_{i, t}+\phi_{i, t} R_{i, d, t}+\gamma_{i, t} \operatorname{sign}\left(R_{i, d, t}^{e}\right) \cdot \text { Volume }_{i, d, t}+\varepsilon_{i, t}
$$

Where $R_{i, d, t}$ is return rate of stock on day $d$ in period $t . R_{i, d, t}^{e}$ is the abnormal return on day $d$ in period $t . \operatorname{sign}\left(R_{i, d, t}^{e}\right)$ $=-1$, when $R_{i, d, t}^{e}<0 ; \operatorname{sign}\left(R_{i, d, t}^{e}\right)=0$, when $R_{i, d, t}^{e}=0 ; \operatorname{sign}\left(R_{i, d, t}^{e}\right)=1$, when $R_{i, d, t}^{e}>0$. Volume $e_{i, d, t}$ is the firm's stock trading volume on day $d$ in period $t . K M T_{t}$ are the market risk factors in period $t$, which equals to the market portfolio return minus the risk-free interest rate. The risk-free interest rate is the month deposit rate of Bank of Taiwan. $S M B_{t}$ is the scale risk factor in period $t$, including large-scale and small-scale factor based on the market value of the stock. $H M L_{t}$ are the net market value ratio risk factors and is divided into three levels, the highest $30 \%$, the middle $40 \%$, and the lowest $30 \%$. Market $t_{i}$ is equal to 1 when the sample is listed on the Taiwan Stock Exchange, and zero otherwise. Industry $y_{i, j}$ is equal to 1 if the company is industry $j$, and zero otherwise.

The description of a measure of earnings management is depicted as follows. First, using the modified Jones model, abnormal total discretionary accruals $\left(A T D A_{i, t}\right)$, abnormal discretionary current accruals $\left(A D C A_{i, t}\right)$ and abnormal discretionary long-term accruals $\left(A D L A_{i, t}\right)$ are estimated in the following models.

$$
A T D A_{i, t}=\frac{T A_{i, t}}{A_{i, t-1}}-\left[\hat{\alpha}_{0}+\hat{\alpha}_{1}\left(\frac{1}{A_{i, t-1}}\right)+\hat{\alpha}_{2}\left(\frac{\Delta S A L E S_{i, t}-\Delta A R_{i, t}}{A_{i, t-1}}\right)+\hat{\alpha}_{3}\left(\frac{P P E_{i, t}}{A_{i, t-1}}\right)\right]
$$

Where $T A_{i, t}=N I_{i, t}-C F O_{i, t} \cdot N I_{i, t}$ is the net profit of firm $i$ in period $t$. the first t. $C F O_{i, t}$ is the cash flow from operating activities of firm $i$ in period $t . A_{i, t-1}$ is the total asset of firm $i$ in the period $t-1 . \triangle S A L E S_{i, t}$ is the change amount of sales revenue of firm $i$ between period $t$ and $t-1 . \triangle A R_{i, t}$ is the change in the amount of accounts receivable between period $t$ and $t-1 . P P E_{i, t}$ is the total amount of fixed assets of firm $i$ in period $t$.

$$
A D C A_{i, t}=\frac{\Delta C A_{i, t}-\Delta C A S H_{i, t}-\Delta C L_{i, t}-\Delta S T D_{i, t}}{A_{i, t-1}}-\left[\hat{\alpha}_{0}+\hat{\alpha}_{1}\left(\frac{1}{A_{i, t-1}}\right)+\hat{\alpha}_{2}\left(\frac{\Delta S A E S_{i, t}-\Delta A R_{i, t}}{A_{i, t-1}}\right)\right]
$$

Where $\Delta C A_{i, t}$ is the change amount of current assets of firm $i$ in period $t . \Delta C A S H_{i, t}$ is the change amount of cash of firm $i$ in period $t . \Delta C L_{i, t}$ is the change amount of current liabilities of firm $i$ in period $t . \Delta S T D_{i, t}$ is the change amount of long-term debt due within one year for the firm $i$ in period $t$. The definitions of other variables are same as those of equations (3). The abnormal long-term discretionary accruals can be obtained using the total abnormal discretionary accruals measured by formula (3) minus the abnormal current discretionary accruals measured by formula (4).

Essence of real earnings management is the use of cash flow from operation, production costs, and discretionary expenses as indicators to manipulate earnings. Manipulation methods described in the followings affect the abnormal levels of three indicators above. The first is the excessive price discounts and production will lead to an abnormally high production costs, thus reducing the cash flow from operation. Second, reducing discretionary expenditure results in abnormally low discretionary expenses, but has higher cash flow from operation. Therefore, under the fixed sales revenue, real earnings manipulation will result in abnormally low cash flow from operation and discretionary expenses, but will increase abnormal production costs. Thus come up with real earnings management model is as follows: 


$$
\begin{gathered}
\frac{\text { FFO }_{i, t}}{A_{i, t-1}}=\hat{\alpha}_{0}+\hat{\alpha}_{1} \frac{1}{A_{i, t-1}}+\hat{\alpha}_{2} \frac{\operatorname{SALES}_{i, t}}{A_{i, t-1}}+\hat{\alpha}_{3} \frac{\Delta S A L E S_{i, t}}{A_{i, t-1}}, \\
\frac{P \operatorname{Cost}_{i, t}}{A_{i, t-1}}=\hat{\alpha}_{0}+\hat{\alpha}_{1} \frac{1}{A_{i, t-1}}+\hat{\alpha}_{2} \frac{\operatorname{SALES}_{i t}}{A_{i, t-1}}+\hat{\alpha}_{3} \frac{\Delta S A L E S_{i, t}}{A_{i, t-1}}+\hat{\alpha}_{4} \frac{\Delta S A L E S_{i, t-1}}{A_{i, t-1}}, \\
\frac{\text { Dexpense }_{i, t}}{A_{i, t-1}}=\hat{\alpha}_{0}+\hat{\alpha}_{1} \frac{1}{A_{i, t-1}}+\hat{\alpha}_{2} \frac{S A L S E_{i, t-1}}{A_{i, t-1}},
\end{gathered}
$$

Where $C F O_{i, t}$ is cash flow from operation of firm $i$ in period $t$. PCost $t_{i, t}$ is the production costs of firm $i$ in period $t$. DExpense $_{i, t}$ is discretionary expenses of firm $i$ in period $t$, including advertising, research and development, management and marketing costs. SALES $S_{i, t}$ is sales revenue of firm $i$ in period $t . \triangle S A L E S_{i, t}$ is the change amount of sales revenue between period $t$ and period $t-1$. SALES $S_{i, t-1}$ is sales revenue of firm $i$ in period $t-1 . \triangle S A L E S_{i, t-1}$ is the change amount of sales revenue between period $t-1$ and period $t-2$. The standard estimate of real earnings management is obtained from equation (5) to equation (7). The abnormal cash flow from operation is obtained using the actual cash flow from operation minus the standard cash flow equation (5). Similarly, abnormal production costs can be obtained using the actual cost minus production formula (6); and abnormal discretionary expenses is the actual discretionary expenses minus formula (7).

\section{Empirical Results}

\subsection{Summary Statistics}

Table 2 shows the summary statistics of variables. The average abnormal stock returns derived from Fama French three-factor model is -0.31 with skewed to the right median of -1.60 . In addition, there are a few companies whose abnormal returns are less than zero. It may be due to the economic condition with the stock index during the sample period in relatively low. Therefore, investors pick on firms with good earnings quality or

\begin{tabular}{|c|c|c|c|c|c|}
\hline & Mean & Median & Maximum & Minimum & Std. dev. \\
\hline$A R$ & -0.3039 & -1.5992 & 275.45 & -82.02 & 16.2655 \\
\hline$A D C A$ & -0.0011 & -0.0040 & 3.7654 & -8.5938 & 0.2029 \\
\hline$A D L A$ & 0.0006 & -0.0004 & 8.3518 & -4.1949 & 0.2188 \\
\hline$A T D A$ & -0.0005 & -0.0018 & 2.3024 & -1.8118 & 0.1309 \\
\hline$A C F O$ & -0.0035 & -0.0056 & 1.2892 & -3.9988 & 0.1365 \\
\hline$A P C$ & 0.0115 & 0.0163 & 3.2432 & -2.0220 & 0.1708 \\
\hline$A D E$ & -0.0085 & -0.0158 & 0.8805 & -0.9796 & 0.0775 \\
\hline LiRisk & -0.0004 & 0.0590 & 10.5020 & -10.8038 & 1.0019 \\
\hline MLiRisk & -0.0010 & -0.0582 & 11.5654 & -3.0606 & 1.0317 \\
\hline Liqui & $-5.79 \mathrm{E}+09$ & 1.5060 & $7.59 \mathrm{E}+13$ & $-8.77 \mathrm{E}+13$ & $1.13 \mathrm{E}+12$ \\
\hline MLiqui & 232.10 & -58.77 & 72917 & -18908 & 5416 \\
\hline Volume & 0.1799 & 0.0950 & 2.9105 & $3.08 \mathrm{E}-06$ & 0.2303 \\
\hline PVolume & 0.1832 & 0.0972 & 22.7200 & $2.98 \mathrm{E}-06$ & 0.2402 \\
\hline$M K T$ & 0.3207 & -0.0019 & 51.1862 & -26.5584 & 9.0207 \\
\hline$S M B$ & 1.5320 & 1.3328 & 18.8803 & -24.9800 & 4.2383 \\
\hline$H M L$ & 1.0543 & 0.9800 & 25.8576 & -29.1351 & 4.9570 \\
\hline
\end{tabular}
high liquidity to achieve high stock return.

Table 2. Descriptive statistics for the measures in the first regression equation

Note. $A R=$ abnormal return; $A D C A=$ abnormal discretionary current accruals; $A D L A=$ abnormal discretionary long-term accruals; $A T D A=$ abnormal total discretionary accruals; $A C F O=$ abnormal cash flow from operation; $A P C=$ abnormal production costs; $A D E=$ abnormal discretionary expenses; Volume $=$ monthly average trading volume; $P$ Volume $=$ monthly average trading amount; LiRisk= firm liquidity risk; MLiRisk =market liquidity risk; Liqui= firm liquidity; MLiqui $=$ market liquidity; $M K T=$ market premium factor; $S M B=$ size factor; $H M L=$ book-to-market factor. 
Except for the abnormal discretionary long-term accruals, averages and medians of abnormal discretionary current accruals and abnormal total discretionary accruals are negative. Most of the firms might experience low earnings in the sample period and take discretionary write-offs to reduce further the current period's earnings as the big bath theory of earnings management suggests. The statistics present real earnings management by observing averages and medians of cash flow from operation and discretionary expenses is negative as well as unusual observation of positive averages and medians on production costs. Individual stock liquidity standard deviation is relative large with average skewed to the left and a median of 1.51. Market liquidity is relatively high, so the market's liquidity risk is relatively low.

Table 3 shows the Pearson and Spearman correlation coefficient of equity cost of capital, earnings quality and liquidity with other variables. The correlation coefficients for earnings quality and liquidity and the cost of equity capital are consistent. The three indicators of discretionary accruals are positively associated with the cost of equity, but the ones of real earnings management have an opposite relationship. That is, when the company implementing discretionary accruals, the cost of capital will increase, vice versa for the real earnings management. Stock trading volume is positively related to the cost of equity capital. Whether it is individual stock liquidity or market liquidity risk, the relationship is in inverse to the cost of equity. The higher the liquidity risk, the lower the cost of equity capital. This is not corresponding to our hypothesis which previous empirical results show.

Table 3. The correlation matrix on the variables of earnings quality, liquidity and the cost of equity

\begin{tabular}{|c|c|c|c|c|c|c|c|c|c|c|c|c|c|}
\hline Correlation & $A R$ & $A D C A$ & $A T D A$ & $A D L A$ & $A C F O$ & $A P C$ & $A D E$ & Volume & PVolume & LiRisk & MLiRisk & Liqui & MLiqui \\
\hline$A R$ & & 0.0200 & 0.0236 & 0.0048 & 0.0372 & -0.0351 & 0.0128 & 0.2112 & 0.1718 & -0.0961 & -0.0408 & 0.0403 & -0.0448 \\
\hline$A D C A$ & 0.0151 & & 0.2097 & -0.6314 & -0.1282 & -0.0265 & 0.0208 & -0.0021 & -0.0027 & -0.0061 & -0.0013 & -0.0023 & -0.0006 \\
\hline$A T D A$ & 0.0268 & 0.1749 & & 0.5226 & -0.5378 & 0.0938 & 0.0010 & 0.0204 & 0.0191 & -0.0260 & 0.0042 & 0.0370 & 0.0045 \\
\hline$A D L A$ & 0.0025 & -0.8016 & 0.4485 & & -0.2852 & 0.1017 & -0.0081 & 0.0114 & 0.0108 & -0.0081 & 0.0025 & 0.0228 & 0.0022 \\
\hline$A C F O$ & 0.0139 & -0.1476 & -0.6775 & -0.2774 & & -0.4174 & 0.0860 & 0.0209 & 0.0183 & -0.0088 & -0.0042 & 0.0517 & -0.0044 \\
\hline$A P C$ & -0.0162 & -0.0181 & 0.1528 & 0.1093 & -0.3682 & & -0.5577 & 0.0709 & 0.0727 & 0.0294 & 0.0071 & -0.0123 & 0.0075 \\
\hline$A D E$ & 0.0193 & -0.0153 & -0.0493 & -0.016 & 0.1015 & -0.5102 & & -0.0798 & -0.0803 & -0.0032 & 0.0037 & -0.0411 & 0.0031 \\
\hline Volume & 0.2775 & -0.001 & 0.0046 & 0.0037 & 0.0424 & 0.0283 & -0.0292 & & 0.9983 & -0.2786 & 0.0111 & 0.0721 & 0.0075 \\
\hline PVolume & 0.1992 & -0.0022 & 0.0029 & 0.0038 & 0.0396 & 0.0276 & -0.0302 & 0.9311 & & -0.2782 & 0.0119 & 0.0691 & 0.0084 \\
\hline LiRisk & -0.0841 & 0.0015 & -0.0002 & -0.0015 & -0.0132 & 0.001 & 0.0101 & -0.1561 & -0.1476 & & 0.0155 & -0.0129 & 0.0207 \\
\hline MLiRisk & -0.0075 & 0.0009 & -0.0008 & -0.0013 & 0.0009 & 0.0025 & -0.0078 & -0.0225 & -0.0226 & 0.014 & & 0.0041 & 0.9947 \\
\hline Liqui & 0.0025 & 0.0025 & -0.0038 & -0.0046 & -0.0025 & 0.0045 & -0.001 & -0.0041 & -0.0043 & -0.0006 & 0.0091 & & 0.0034 \\
\hline MLiqui & -0.0078 & 0.002 & 0.0003 & -0.0017 & -0.0003 & 0.0037 & -0.009 & -0.0232 & -0.0233 & 0.0137 & 0.9679 & 0.0099 & \\
\hline
\end{tabular}

Note. $A R=$ abnormal return; $A D C A=$ abnormal discretionary current accruals; $A D L A=$ abnormal discretionary long-term accruals; $A T D A=$ abnormal total discretionary accruals; $A C F O=$ abnormal cash flow from operation; $A P C=$ abnormal production costs; $A D E=$ abnormal discretionary expenses; Volume $=$ monthly average trading volume; PVolume $=$ monthly average trading amount; LiRisk= firm liquidity risk; MLiRisk =market liquidity risk; Liqui= firm liquidity; MLiqui= market liquidity. Pearson correlations are displayed below the main diagonal and Spearman correlations are displayed above the diagonal in Table.

\subsection{Effects of Earning Management and Liquidity}

From either Lagrange multiplier test or Hausman's test, the results of panel data regression equation are valid with fixed effects. Panel A and Panel B in Table 4 present volume and transaction value respectively. The results find that three indicators of discretionary accruals all hold significant positive relationship with the cost of equity capital, especially for long-term and total accruals. Investors request higher cost of equity capital when a company has poor earnings quality of accruals, especially the results show that the long-term accruals are three percent than current accruals (Panel A: $0.674 \times 23.77 \%-0.471 \times 26.22 \%$; Panel B: $0.68 \times 24.18 \%-0.5178 \times$ 26.68\%). The results support hypothesis 1 . 
Table 4. The fixed effects results of the influence of earnings quality and liquidity on the cost of equity

\begin{tabular}{|c|c|c|c|c|c|c|c|}
\hline Panel A & & & & $A R$ & & & \\
\hline Intercept & $-2.7042 * * *$ & $-2.6847 * * *$ & $-2.6809 * * *$ & $-2.7073 * * *$ & $-2.7513 * * *$ & $-2.7364 * * *$ & $-2.7519 * * *$ \\
\hline & $(0.2329)$ & $(0.2329)$ & $(0.2328)$ & $(0.2328)$ & $(0.2331)$ & $(0.2330)$ & $(0.2331)$ \\
\hline$A D C A$ & $0.4705 *$ & & & & & & \\
\hline & $(0.2622)$ & & & & & & \\
\hline$A D L A$ & & $0.6736 * * *$ & & & & & \\
\hline & & $(0.2377)$ & & & & & \\
\hline$A T D A$ & & & $2.8729 * * *$ & & & & \\
\hline & & & $(0.3911)$ & & & & \\
\hline$A C F O$ & & & & $1.0180 * * *$ & & & \\
\hline & & & & $(0.3544)$ & & & \\
\hline$A P C$ & & & & & $-1.2564 * * *$ & & \\
\hline & & & & & $(0.2968)$ & & \\
\hline$A D E$ & & & & & & $2.7603 * * *$ & \\
\hline & & & & & & $(0.6381)$ & \\
\hline CREM & & & & & & & $-0.8261 * * *$ \\
\hline & & & & & & & $(0.1683)$ \\
\hline Volume & $14.3486 * * *$ & $14.3501 * * *$ & $14.3360 * * *$ & $14.3236 * * *$ & $14.3577 * * *$ & $14.3513 * * *$ & $14.3330 * * *$ \\
\hline & $(0.2155)$ & $(0.2155)$ & $(0.2154)$ & $(0.2157)$ & $(0.2155)$ & $(0.2155)$ & $(0.2155)$ \\
\hline LiRisk & $-0.7963 * * *$ & $-0.7965 * * *$ & $-0.7969 * * *$ & $-0.7953 * * *$ & $-0.7952 * * *$ & $-0.7982 * * *$ & $-0.7952 * * *$ \\
\hline & $(0.0491)$ & $(0.0491)$ & $(0.0491)$ & $(0.0491)$ & $(0.0491)$ & $(0.0491)$ & $(0.0491)$ \\
\hline MLiRisk & $0.4818 * *$ & $0.4776 * *$ & $0.4829 * *$ & $0.4763 * *$ & $0.4759 * *$ & $0.4751 * *$ & $0.4735 * *$ \\
\hline & $(0.2140)$ & $(0.2140)$ & $(0.2139)$ & $(0.2140)$ & $(0.2140)$ & $(0.2140)$ & $(0.2140)$ \\
\hline Liqui & 4.84E-14 & 4.92E-14 & $4.98 \mathrm{E}-14$ & $4.90 \mathrm{E}-14$ & 4.94E-14 & $4.86 \mathrm{E}-14$ & 4.94E-14 \\
\hline & $(0.0000)$ & $(0.0000)$ & $(0.0000)$ & $(0.0000)$ & $(0.0000)$ & $(0.0000)$ & $(0.0000)$ \\
\hline MLiqui & $-7.93 \mathrm{E}-05 * *$ & $-7.81 \mathrm{E}-05 *$ & $-7.92 \mathrm{E}-05 * *$ & $-7.81 \mathrm{E}-05 *$ & $-7.79 \mathrm{E}-05 *$ & $-7.76 \mathrm{E}-05 *$ & $-7.73 \mathrm{E}-05 *$ \\
\hline & $(0.0000)$ & $(0.0000)$ & $(0.0000)$ & $(0.0000)$ & $(0.0000)$ & $(0.0000)$ & $(0.0000)$ \\
\hline$M K T$ & $0.4923 * * *$ & $0.4897 * * *$ & $0.4914 * * *$ & $0.4913 * * *$ & $0.4928 * * *$ & $0.4904 * * *$ & $0.4922 * * *$ \\
\hline & $(0.0313)$ & $(0.0313)$ & $(0.0313)$ & $(0.0313)$ & $(0.0313)$ & $(0.0313)$ & $(0.0313)$ \\
\hline$S M B$ & $0.1703 * * *$ & $0.1701 * * *$ & $0.1695 * * *$ & $0.1709 * * *$ & $0.1691 * * *$ & $0.1703 * * *$ & $0.1700 * * *$ \\
\hline & $(0.0314)$ & $(0.0314)$ & $(0.0313)$ & $(0.0314)$ & (0.0314) & $(0.0313)$ & $(0.0313)$ \\
\hline$H M L$ & $0.1441 * * *$ & $0.1442 * * *$ & $0.1444 * * *$ & $0.1439 * * *$ & $0.1436 * * *$ & $0.1437 * * *$ & $0.1435 * * *$ \\
\hline & $(0.0229)$ & $(0.0229)$ & $(0.0229)$ & $(0.0229)$ & $(0.0229)$ & $(0.0229)$ & $(0.0229)$ \\
\hline Market & $0.3206 * *$ & $0.2948 * *$ & $0.3076 * *$ & $0.3062 * *$ & $0.3772 * * *$ & $0.3962 * * *$ & $0.3764 * * *$ \\
\hline & $(0.1285)$ & $(0.1285)$ & $(0.1283)$ & $(0.1283)$ & $(0.1293)$ & $(0.1298)$ & $(0.1290)$ \\
\hline Observations & 67634 & 67634 & 67640 & 67640 & 67640 & 67640 & 67640 \\
\hline $\operatorname{Adj} R^{2}$ & 0.4082 & 0.4083 & 0.4087 & 0.4083 & 0.4084 & 0.4084 & 0.4084 \\
\hline
\end{tabular}




\begin{tabular}{|c|c|c|c|c|c|c|c|}
\hline Panel B & & & & & & & \\
\hline \multirow[t]{2}{*}{ Intercept } & $-2.3311 * * *$ & $-2.3109 * * *$ & $-2.3065 * * *$ & $-2.3370 * * *$ & $-2.3761 * * *$ & $-2.3639 * * *$ & $-2.3837 * * *$ \\
\hline & $(0.2369)$ & $(0.2369)$ & $(0.2367)$ & $(0.2368)$ & $(0.2371)$ & $(0.2370)$ & $(0.2370)$ \\
\hline \multirow[t]{2}{*}{$A D C A$} & $0.5178 *$ & & & & & & \\
\hline & $(0.2668)$ & & & & & & \\
\hline \multirow[t]{2}{*}{$A D L A$} & & $0.6794 * * *$ & & & & & \\
\hline & & $(0.2418)$ & & & & & \\
\hline \multirow[t]{2}{*}{$A T D A$} & & & $2.9939 * * *$ & & & & \\
\hline & & & $(0.3979)$ & & & & \\
\hline \multirow[t]{2}{*}{$A C F O$} & & & & $1.4030 * * *$ & & & \\
\hline & & & & $(0.3605)$ & & & \\
\hline \multirow[t]{2}{*}{$A P C$} & & & & & $-1.2282 * * *$ & & \\
\hline & & & & & (0.3019) & & \\
\hline \multirow[t]{2}{*}{$A D E$} & & & & & & $2.8472 * * *$ & \\
\hline & & & & & & $(0.6491)$ & \\
\hline \multirow[t]{2}{*}{ CREM } & & & & & & & $-0.9099 * * *$ \\
\hline & & & & & & & $(0.1712)$ \\
\hline \multirow[t]{2}{*}{ PVolume } & $9.0415 * * *$ & $9.0425 * * *$ & $9.0326 * * *$ & $9.0112 * * *$ & $9.0503 * * *$ & $9.0462 * * *$ & $9.0284 * * *$ \\
\hline & $(0.2013)$ & $(0.2013)$ & $(0.2012)$ & $(0.2014)$ & $(0.2013)$ & $(0.2012)$ & $(0.2013)$ \\
\hline \multirow[t]{2}{*}{ LiRisk } & $-0.9492 * * *$ & $-0.9494 * * *$ & $-0.9498 * * *$ & $-0.9476 * * *$ & $-0.9482 * * *$ & $-0.9511 * * *$ & $-0.9479 * * *$ \\
\hline & $(0.0499)$ & $(0.0499)$ & $(0.0499)$ & $(0.0499)$ & $(0.0499)$ & $(0.0499)$ & $(0.0499)$ \\
\hline \multirow[t]{2}{*}{ MLiRisk } & $0.4179 *$ & $0.4134 *$ & $0.4189 *$ & $0.4111 *$ & $0.4117 *$ & $0.4107 *$ & $0.4087 *$ \\
\hline & $(0.2177)$ & $(0.2177)$ & $(0.2176)$ & $(0.2177)$ & $(0.2176)$ & $(0.2176)$ & $(0.2176)$ \\
\hline \multirow[t]{2}{*}{ Liqui } & 4.36E-14 & 4.45E-14 & 4.51E-14 & 4.44E-14 & 4.46E-14 & $4.39 \mathrm{E}-14$ & $4.48 \mathrm{E}-14$ \\
\hline & $(0.0000)$ & $(0.0000)$ & $(0.0000)$ & $(0.0000)$ & $(0.0000)$ & $(0.0000)$ & $(0.0000)$ \\
\hline \multirow[t]{2}{*}{ MLiqui } & $-6.67 \mathrm{E}-05$ & $-6.55 \mathrm{E}-05$ & $-6.67 \mathrm{E}-05$ & $-6.53 \mathrm{E}-05$ & $-6.53 \mathrm{E}-05$ & $-6.49 \mathrm{E}-05$ & $-6.46 \mathrm{E}-05$ \\
\hline & $(0.0000)$ & $(0.0000)$ & $(0.0000)$ & $(0.0000)$ & $(0.0000)$ & $(0.0000)$ & $(0.0000)$ \\
\hline \multirow[t]{2}{*}{$M K T$} & $0.5321 * * *$ & $0.5294 * * *$ & $0.5311 * * *$ & $0.5311 * * *$ & $0.5325 * * *$ & $0.5301 * * *$ & $0.5320 * * *$ \\
\hline & $(0.0318)$ & $(0.0318)$ & $(0.0318)$ & $(0.0318)$ & $(0.0318)$ & $(0.0318)$ & $(0.0318)$ \\
\hline \multirow[t]{2}{*}{$S M B$} & $0.1993 * * *$ & $0.1991 * * *$ & $0.1984 * * *$ & $0.2001 * * *$ & $0.1982 * * *$ & $0.1992 * * *$ & $0.1989 * * *$ \\
\hline & (0.0319) & $(0.0319)$ & $(0.0319)$ & $(0.0319)$ & $(0.0319)$ & $(0.0319)$ & $(0.0319)$ \\
\hline \multirow[t]{2}{*}{$H M L$} & $0.1460 * * *$ & $0.1462 * * *$ & $0.1464 * * *$ & $0.1457 * * *$ & $0.1456 * * *$ & $0.1457 * * *$ & $0.1454 * * *$ \\
\hline & $(0.0233)$ & $(0.0233)$ & $(0.0233)$ & $(0.0233)$ & $(0.0233)$ & $(0.0233)$ & $(0.0233)$ \\
\hline \multirow[t]{2}{*}{ Market } & $0.5404 * * *$ & $0.5135 * * *$ & $0.5258 * * *$ & $0.5229 * * *$ & $0.5942 * * *$ & $0.6174 * * *$ & $0.6014 * * *$ \\
\hline & $(0.1306)$ & $(0.1306)$ & $(0.1304)$ & $(0.1305)$ & $(0.1314)$ & $(0.1320)$ & $(0.1312)$ \\
\hline Observations & 67634 & 67634 & 67640 & 67640 & 67640 & 67640 & 67640 \\
\hline $\operatorname{Adj} R^{2}$ & 0.3877 & 0.3877 & 0.3882 & 0.3878 & 0.3878 & 0.3878 & 0.3879 \\
\hline
\end{tabular}

Note. $A R=$ abnormal return; $A D C A=$ abnormal discretionary current accruals; $A D L A=$ abnormal discretionary long-term accruals; $A T D A=$ abnormal total discretionary accruals; $A C F O=$ abnormal cash flow from operation; $A P C=$ abnormal production $\operatorname{costs} ; A D E=$ abnormal discretionary expenses; Volume $=$ monthly average trading volume; $P$ Volume $=$ monthly average trading amount; LiRisk= firm liquidity risk; MLiRisk =market liquidity risk; Liqui $=$ firm liquidity; $M L i q u i=$ market liquidity; $M K T=$ market premium factor; $S M B=$ size factor; $H M L=$ book-to-market factor; Market= market dummy. Standard errors are indicated in parentheses. *, **, *** denote statistical significance at the 10 percent, 5 percent and 1 percent levels (two-tailed), respectively. 
The three indicators of real earnings management have significant negative effects on equity costs, with discretionary expenses the most prominent. Discretionary expenses are usually the company's advertising, research and other operating and administrative expenses. If the company did earnings management by reducing the above costs in an aim to increase operating cash flow, then investors would not be able to gather information. Consistent with Deng and Ong (2014) in the sample of REITs, the composite indicator (CREM) is negatively related to the cost of equity. When the company implements real earnings management, thus reduce the cost of equity. Therefore, hypothesis 2 holds.

The relationship between trading volumes and the cost of equity in both Panel A and Panel B is significantly positive which indicating that the greater the amount of stock trading volume, the higher the equity cost. The cost of equity for companies listed in the Taiwan Stock Exchange is higher than that of listed in OTC. Liquidity in Panel A has a significant inverse relationship with the cost of equity capital while market liquidity risk is significantly positive to the cost of equity indicating risk premium compensation. However, there is no significance in Panel B. Market liquidity risk in both Panels is positively associated with the cost of equity, consistent with previous empirical results of risk premium. But individual stock liquidity risk related to the cost is in significantly inverse, implicating the higher the individual liquidity risk, the lower the cost of equity.

\subsection{Effects of Information Asymmetry}

The findings of this study as shown above are different from previous researches. We follow Bhattacharya et al. (2012) and add the factor of information asymmetry which has indirect impact on the equity cost of capital. The bid-ask spread (BAS) as a variable of information asymmetry is calculated by monthly stock prices as follows:

$$
B A S_{i, t}=\frac{\text { askprice }- \text { bidprice }}{(\text { askprice }+ \text { bidprice }) / 2} \times 100 \%
$$

Where askprice is daily selling price for stocks; bidprice is daily purchase price. We rank absolute value of the bid-ask spread, and the large value indicates higher degree of information asymmetry. Companies with higher degree of information asymmetry formed in the first quartile will have dummy variable of HBAS set as one, and otherwise 0 . The same rule applied for the companies in the bottom quartile for dummy variable of LBAS.

The regression equations are set as follows:

$$
\begin{aligned}
& A R_{i, t}=\beta_{0}+\beta_{1} E M_{i, t}+\beta_{2} \text { Volume }_{i, t}\left(\text { PVolume }_{i, t}\right)+\beta_{3} \text { LiRisk }_{i, t}+\beta_{4} H B A S_{i, t}+ \\
& \beta_{5} L_{B A S_{i, t}}+\beta_{6} E M_{i, t} \times H B A S_{i, t}+\beta_{7} E M_{i, t} \times L B A S_{i, t}+ \\
& \beta_{8} \text { Volume }_{i, t}\left(\text { PVolume }_{i, t}\right) \times H B A S_{i, t}+\beta_{9} \text { Volume }_{i, t}\left(\text { PVolume }_{i, t}\right) \times L B A S_{i, t}+ \\
& \beta_{10} \text { LiRisk }_{i, t} \times H B A S_{i, t}+\beta_{11} \text { LiRisk }_{i, t} \times L B A S_{i, t}+\beta_{12} M K T_{t}+\beta_{13} S M B_{t}+\beta_{14} H M L_{t}+\beta_{15} \text { Market }_{i}
\end{aligned}
$$

Except for information asymmetry variables, the other specifications of variables are the same as those in regression equation (1).

The panel data regression results are shown in Table 5. According to the Lagrange multiplier test or Hausman test, only variable (Volume $e_{i, t}$ ) which is monthly average trading volume of the regression equation is significant at the level of 0.01 with fixed effects. However, in regression equation with monthly average trading amount variable $\left(P\right.$ Volume $\left._{i, t}\right)$, the abnormal cash flow from operation $\left(A C F O_{i, t}\right)$ and abnormal production costs $\left(A P C_{i, t}\right)$ show the best estimates under random effects while the rest run the best under fixed effects. Most of the results are similar to the prior findings except for current accruals. But after adding the interaction term of earnings quality indicators and information asymmetry, when there is high degree of information asymmetry, abnormal discretionary current accruals are positively related to the cost of equity. However, abnormal discretionary long-term accruals have an inverse relationship with the cost of equity. Thus, company should opt for long-term discretionary accruals as regulatory agency reform may advise. In addition, when experience higher information asymmetry, firms benefit from doing real earnings management so as to cut cost of equity. On contrary, companies with higher transparency refrain from earnings management, otherwise the cost of equity increases.

Under the lower level of information asymmetry, with the increase of stock trading volume and stock liquidity risk will decrease in the cost of equity capital. This incompletely supports hypothesis 3 . That is, firms benefits from the advantage of lower information asymmetry which reduces the equity of cost. 
Table 5. The panel results from the cost of equity indirectly influenced by earnings quality and liquidity through information asymmetry

\begin{tabular}{|c|c|c|c|c|c|c|c|}
\hline \multirow[b]{2}{*}{ Panel A } & \multicolumn{7}{|c|}{$A R$} \\
\hline & & & & Fixed effects & & & \\
\hline \multirow[t]{2}{*}{ Intercept } & $-3.3320 * * *$ & $-3.3149 * * *$ & $-3.3130 * * *$ & $-3.3849 * * *$ & $-3.4091 * * *$ & $-3.3686 * * *$ & $-3.4256 * * *$ \\
\hline & $(0.2357)$ & $(0.2357)$ & $(0.2356)$ & $(0.2358)$ & $(0.2362)$ & $(0.2358)$ & $(0.2360)$ \\
\hline \multirow[t]{2}{*}{$A D C A$} & -0.5662 & & & & & & \\
\hline & $(0.3783)$ & & & & & & \\
\hline \multirow[t]{2}{*}{$A D L A$} & & $1.3897 * * *$ & & & & & \\
\hline & & $(0.3458)$ & & & & & \\
\hline \multirow[t]{2}{*}{$A T D A$} & & & $2.8873 * * *$ & & & & \\
\hline & & & $(0.6147)$ & & & & \\
\hline \multirow[t]{2}{*}{$A C F O$} & & & & $3.9153 * * *$ & & & \\
\hline & & & & $(0.5762)$ & & & \\
\hline \multirow[t]{2}{*}{$A P C$} & & & & & $-2.0833 * * *$ & & \\
\hline & & & & & $(0.4608)$ & & \\
\hline \multirow[t]{2}{*}{$A D E$} & & & & & & $2.7745 * * *$ & \\
\hline & & & & & & $(0.8684)$ & \\
\hline \multirow[t]{2}{*}{ CREM } & & & & & & & $-1.6344 * * *$ \\
\hline & & & & & & & $(0.2544)$ \\
\hline \multirow[t]{2}{*}{ Volmue } & $11.2413 * * *$ & $11.2400 * * *$ & $11.2285 * * *$ & $11.1788 * * *$ & $11.2994 * * *$ & $11.2635 * * *$ & $11.2637 * * *$ \\
\hline & $(0.3190)$ & $(0.3190)$ & $(0.3189)$ & $(0.3191)$ & $(0.3193)$ & $(0.3191)$ & $(0.3190)$ \\
\hline \multirow[t]{2}{*}{ LiRisk } & $-0.5747 * * *$ & $-0.5743 * * *$ & $-0.5771 * * *$ & $-0.5823 * * *$ & $-0.5709 * * *$ & $-0.5730 * * *$ & $-0.5727 * * *$ \\
\hline & $(0.0998)$ & (0.0998) & $(0.0997)$ & (0.0998) & $(0.0998)$ & $(0.0998)$ & $(0.0998)$ \\
\hline \multirow[t]{2}{*}{$H B A S$} & $0.5593 * * *$ & $0.5529 * * *$ & $0.5901 * * *$ & $0.5530 * * *$ & $0.6098 * * *$ & $0.5602 * * *$ & $0.6005 * * *$ \\
\hline & $(0.1488)$ & $(0.1489)$ & $(0.1489)$ & $(0.1492)$ & $(0.1491)$ & $(0.1489)$ & $(0.1492)$ \\
\hline \multirow[t]{2}{*}{$L B A S$} & $0.8089 * * *$ & $0.8026 * * *$ & $0.8077 * * *$ & $0.7984 * * *$ & $0.7883 * * *$ & $0.7790 * * *$ & $0.7931 * * *$ \\
\hline & $(0.1524)$ & $(0.1524)$ & $(0.1523)$ & $(0.1524)$ & $(0.1528)$ & $(0.1537)$ & $(0.1526)$ \\
\hline \multirow[t]{2}{*}{$A D C A \times H B A S$} & $3.0723 * * *$ & & & & & & \\
\hline & $(0.6005)$ & & & & & & \\
\hline \multirow[t]{2}{*}{$A D C A \times L B A S$} & 0.0209 & & & & & & \\
\hline & $(0.6514)$ & & & & & & \\
\hline \multirow[t]{2}{*}{$A D L A \times H B A S$} & & $-1.9973 * * *$ & & & & & \\
\hline & & $(0.5435)$ & & & & & \\
\hline \multirow[t]{2}{*}{$A D L A \times L B A S$} & & 0.1917 & & & & & \\
\hline & & $(0.5930)$ & & & & & \\
\hline \multirow[t]{2}{*}{$A T D A \times H B A S$} & & & 0.3904 & & & & \\
\hline & & & $(0.8861)$ & & & & \\
\hline \multirow[t]{2}{*}{$A T D A \times L B A S$} & & & 0.0464 & & & & \\
\hline & & & $(0.9886)$ & & & & \\
\hline \multirow[t]{2}{*}{$A C F O \times H B A S$} & & & & $-5.0178 * * *$ & & & \\
\hline & & & & $(0.7942)$ & & & \\
\hline \multirow[t]{2}{*}{$A C F O \times L B A S$} & & & & $-2.0931 * *$ & & & \\
\hline & & & & (0.9293) & & & \\
\hline \multirow[t]{2}{*}{$A P C \times H B A S$} & & & & & 0.1113 & & \\
\hline & & & & & $(0.6571)$ & & \\
\hline
\end{tabular}




\begin{tabular}{|c|c|c|c|c|c|c|c|}
\hline \multirow[t]{2}{*}{$A P C \times L B A S$} & & & \multicolumn{5}{|c|}{$2.3656 * * *$} \\
\hline & & & & & $(0.7534)$ & & \\
\hline \multirow[t]{2}{*}{$A D E \times H B A S$} & & & & & & $2.8062 *$ & \\
\hline & & & & & & (1.5557) & \\
\hline \multirow[t]{2}{*}{$A D E \times L B A S$} & & & & & & $-2.8857 * *$ & \\
\hline & & & & & & $(1.4652)$ & \\
\hline \multirow[t]{2}{*}{$C R E M \times H B A S$} & & & & & & & $0.9583 * *$ \\
\hline & & & & & & & $(0.3790)$ \\
\hline \multirow[t]{2}{*}{$C R E M \times L B A S$} & & & & & & & $1.3482 * * *$ \\
\hline & & & & & & & $(0.4190)$ \\
\hline \multirow[t]{2}{*}{ Volume $\times H B A S$} & 15.7296 *** & $15.7423 * * *$ & $15.7156 * * *$ & $15.8291 * * *$ & $15.6669 * * *$ & $15.7462 * * *$ & $15.6596 * * *$ \\
\hline & $(0.4824)$ & $(0.4824)$ & $(0.4823)$ & $(0.4828)$ & $(0.4828)$ & $(0.4827)$ & $(0.4824)$ \\
\hline \multirow[t]{2}{*}{ Volume $\times L B A S$} & $-3.9012 * * *$ & $-3.8926 * * *$ & $-3.8886 * * *$ & $-3.8581 * * *$ & $-3.9529 * * *$ & $-3.9189 * * *$ & $-3.9307 * * *$ \\
\hline & $(0.4698)$ & $(0.4699)$ & $(0.4697)$ & $(0.4700)$ & $(0.4700)$ & $(0.4699)$ & $(0.4698)$ \\
\hline \multirow[t]{2}{*}{ LiRisk $\times H B A S$} & 0.0148 & 0.0160 & 0.0156 & 0.0234 & 0.0113 & 0.0079 & 0.0149 \\
\hline & $(0.1136)$ & $(0.1136)$ & $(0.1135)$ & $(0.1135)$ & $(0.1136)$ & $(0.1136)$ & $(0.1135)$ \\
\hline \multirow[t]{2}{*}{ LiRisk $\times L B A S$} & $-1.9011 * * *$ & $-1.8944 * * *$ & $-1.8720 * * *$ & $-1.9095 * * *$ & $-1.9353 * * *$ & $-1.9247 * * *$ & $-1.9200 * * *$ \\
\hline & $(0.2494)$ & $(0.2494)$ & $(0.2494)$ & $(0.2493)$ & $(0.2500)$ & $(0.2499)$ & $(0.2497)$ \\
\hline \multirow[t]{2}{*}{$M K T$} & $0.4829 * * *$ & $0.4795 * * *$ & $0.4811 * * *$ & $0.4822 * * *$ & $0.4837 * * *$ & $0.4801 * * *$ & $0.4825 * * *$ \\
\hline & $(0.0304)$ & $(0.0304)$ & $(0.0303)$ & $(0.0303)$ & $(0.0304)$ & $(0.0304)$ & $(0.0304)$ \\
\hline \multirow[t]{2}{*}{$S M B$} & $0.1583 * * *$ & $0.1584 * * *$ & $0.1576 * * *$ & $0.1589 * * *$ & $0.1575 * * *$ & $0.1588 * * *$ & $0.1580 * * *$ \\
\hline & $(0.0305)$ & $(0.0305)$ & $(0.0305)$ & $(0.0305)$ & $(0.0305)$ & $(0.0305)$ & $(0.0305)$ \\
\hline \multirow[t]{2}{*}{$H M L$} & $0.1509 * * *$ & $0.1502 * * *$ & $0.1512 * * *$ & $0.1513 * * *$ & $0.1507 * * *$ & $0.1505 * * *$ & $0.1506 * * *$ \\
\hline & $(0.0224)$ & $(0.0224)$ & $(0.0224)$ & $(0.0224)$ & $(0.0224)$ & $(0.0224)$ & $(0.0224)$ \\
\hline \multirow[t]{2}{*}{ Market } & $0.8570 * * *$ & $0.8318 * * *$ & $0.8567 * * *$ & $0.8774 * * *$ & $0.9410 * * *$ & $0.9366 * * *$ & $0.9585 * * *$ \\
\hline & $(0.1318)$ & $(0.1318)$ & $(0.1316)$ & $(0.1317)$ & $(0.1329)$ & $(0.1330)$ & $(0.1326)$ \\
\hline Observations & 67665 & 67665 & 67671 & 67671 & 67671 & 67671 & 67671 \\
\hline $\operatorname{Adj} R^{2}$ & 0.4294 & 0.4294 & 0.4296 & 0.4296 & 0.4294 & 0.4294 & 0.4295 \\
\hline \multirow[t]{2}{*}{ Hausman test } & $298.08 * * *$ & $300.35 * * *$ & $300.72 * * *$ & $309.86 * * *$ & $301.50 * * *$ & $320.93 * * *$ & $302.40 * * *$ \\
\hline & $(0.0000)$ & $(0.0000)$ & $(0.0000)$ & $(0.0000)$ & $(0.0000)$ & $(0.0000)$ & $(0.0000)$ \\
\hline Panel B & & & & Fixed effects & & & \\
\hline \multirow[t]{2}{*}{ Intercept } & $-3.2439 * * *$ & $-3.2262 * * *$ & $-3.2237 * * *$ & $-3.3014 * * *$ & $-3.3210 * * *$ & $-3.2792 * * *$ & $-3.3435 * * *$ \\
\hline & $(0.2403)$ & $(0.2404)$ & $(0.2403)$ & $(0.2405)$ & $(0.2409)$ & $(0.2405)$ & $(0.2407)$ \\
\hline \multirow[t]{2}{*}{$A D C A$} & -0.5534 & & & & & & \\
\hline & $(0.3857)$ & & & & & & \\
\hline \multirow[t]{2}{*}{$A D L A$} & & $1.3951 * * *$ & & & & & \\
\hline & & $(0.3526)$ & & & & & \\
\hline \multirow[t]{2}{*}{$A T D A$} & & & $2.9378 * * *$ & & & & \\
\hline & & & $(0.6267)$ & & & & \\
\hline \multirow[t]{2}{*}{$A C F O$} & & & & $4.1508 * * *$ & & & \\
\hline & & & & $(0.5873)$ & & & \\
\hline \multirow[t]{2}{*}{$A P C$} & & & & & $-2.0540 * * *$ & & \\
\hline & & & & & $(0.4699)$ & & \\
\hline \multirow[t]{2}{*}{$A D E$} & & & & & & $2.9250 * * *$ & \\
\hline & & & & & & $(0.8854)$ & \\
\hline
\end{tabular}




\begin{tabular}{|c|c|c|c|c|c|c|c|}
\hline CREM & & & & & & & $-1.6850 * * *$ \\
\hline & & & & & & & $(0.2593)$ \\
\hline PVolmue & $8.1202 * * *$ & $8.1202 * * *$ & $8.1105 * * *$ & $8.0615 * * *$ & $8.1795 * * *$ & $8.1435 * * *$ & $8.1492 * * *$ \\
\hline & $(0.3202)$ & $(0.3202)$ & $(0.3201)$ & $(0.3203)$ & $(0.3205)$ & $(0.3203)$ & $(0.3202)$ \\
\hline Lirisk & $-0.6673 * * *$ & $-0.6668 * * *$ & $-0.6697 * * *$ & $-0.6747 * * *$ & $-0.6635 * * *$ & $-0.6654 * * *$ & $-0.6650 * * *$ \\
\hline & $(0.1017)$ & $(0.1018)$ & $(0.1017)$ & $(0.1017)$ & $(0.1017)$ & $(0.1018)$ & $(0.1017)$ \\
\hline$H B A S$ & $1.0735 * * *$ & $1.0683 * * *$ & $1.1076 * * *$ & $1.0803 * * *$ & $1.1254 * * *$ & $1.0749 * * *$ & $1.1221 * * *$ \\
\hline & $(0.1524)$ & $(0.1525)$ & $(0.1525)$ & $(0.1528)$ & $(0.1527)$ & $(0.1524)$ & $(0.1528)$ \\
\hline$L B A S$ & $1.2112 * * *$ & $1.2056 * * *$ & $1.2092 * * *$ & $1.1991 * * *$ & $1.1944 * * *$ & $1.1893 * * *$ & $1.1976 * * *$ \\
\hline & $(0.1482)$ & $(0.1482)$ & $(0.1480)$ & $(0.1482)$ & $(0.1486)$ & $(0.1495)$ & $(0.1484)$ \\
\hline$A D C A \times H B A S$ & $3.1717 * * *$ & & & & & & \\
\hline & $(0.6122)$ & & & & & & \\
\hline$A D C A \times L B A S$ & 0.0776 & & & & & & \\
\hline & $(0.6641)$ & & & & & & \\
\hline$A D L A \times H B A S$ & & $-2.0010 * * *$ & & & & & \\
\hline & & $(0.5542)$ & & & & & \\
\hline$A D L A \times L B A S$ & & 0.1481 & & & & & \\
\hline & & $(0.6046)$ & & & & & \\
\hline$A T D A \times H B A S$ & & & 0.5531 & & & & \\
\hline & & & $(0.9033)$ & & & & \\
\hline$A T D A \times L B A S$ & & & 0.0455 & & & & \\
\hline & & & (1.0079) & & & & \\
\hline$A C F O \times H B A S$ & & & & $-4.7408 * * *$ & & & \\
\hline & & & & $(0.8096)$ & & & \\
\hline$A C F O \times L B A S$ & & & & $-2.1765 * *$ & & & \\
\hline & & & & $(0.9473)$ & & & \\
\hline$A P C \times H B A S$ & & & & & 0.0879 & & \\
\hline & & & & & $(0.6700)$ & & \\
\hline$A P C \times L B A S$ & & & & & $2.1681 * * *$ & & \\
\hline & & & & & $(0.7681)$ & & \\
\hline$A D E \times H B A S$ & & & & & & 2.1533 & \\
\hline & & & & & & (1.5863) & \\
\hline$A D E \times L B A S$ & & & & & & $-2.4694 *$ & \\
\hline & & & & & & (1.4938) & \\
\hline$C R E M \times H B A S$ & & & & & & & $0.8983 * *$ \\
\hline & & & & & & & $(0.3864)$ \\
\hline$C R E M \times L B A S$ & & & & & & & $1.2690 * * *$ \\
\hline & & & & & & & $(0.4272)$ \\
\hline PVolume $\times H B A S$ & $13.0023 * * *$ & $13.0087 * * *$ & $12.9802 * * *$ & $13.0725 * * *$ & $12.9339 * * *$ & $13.0082 * * *$ & $12.9157 * * *$ \\
\hline & $(0.4929)$ & $(0.4929)$ & $(0.4928)$ & $(0.4932)$ & $(0.4933)$ & $(0.4932)$ & $(0.4929)$ \\
\hline PVolume $\times L B A S$ & $-4.8356 * * *$ & $-4.8309 * * *$ & $-4.8234 * * *$ & $-4.7940 * * *$ & $-4.8893 * * *$ & $-4.8572 * * *$ & $-4.8697 * * *$ \\
\hline & $(0.4284)$ & $(0.4284)$ & $(0.4283)$ & $(0.4285)$ & $(0.4285)$ & $(0.4284)$ & $(0.4283)$ \\
\hline LiRisk $\times H B A S$ & -0.0480 & -0.0469 & -0.0474 & -0.0393 & -0.0515 & -0.0543 & -0.0484 \\
\hline & $(0.1158)$ & $(0.1158)$ & $(0.1158)$ & $(0.1158)$ & $(0.1158)$ & $(0.1158)$ & $(0.1158)$ \\
\hline LiRisk $\times L B A S$ & $-1.8220 * * *$ & $-1.8160 * * *$ & $-1.7936 * * *$ & $-1.8329 * * *$ & $-1.8520 * * *$ & $-1.8392 * * *$ & $-1.8385 * * *$ \\
\hline & $(0.2543)$ & $(0.2543)$ & $(0.2543)$ & $(0.2542)$ & $(0.2549)$ & $(0.2548)$ & $(0.2546)$ \\
\hline
\end{tabular}




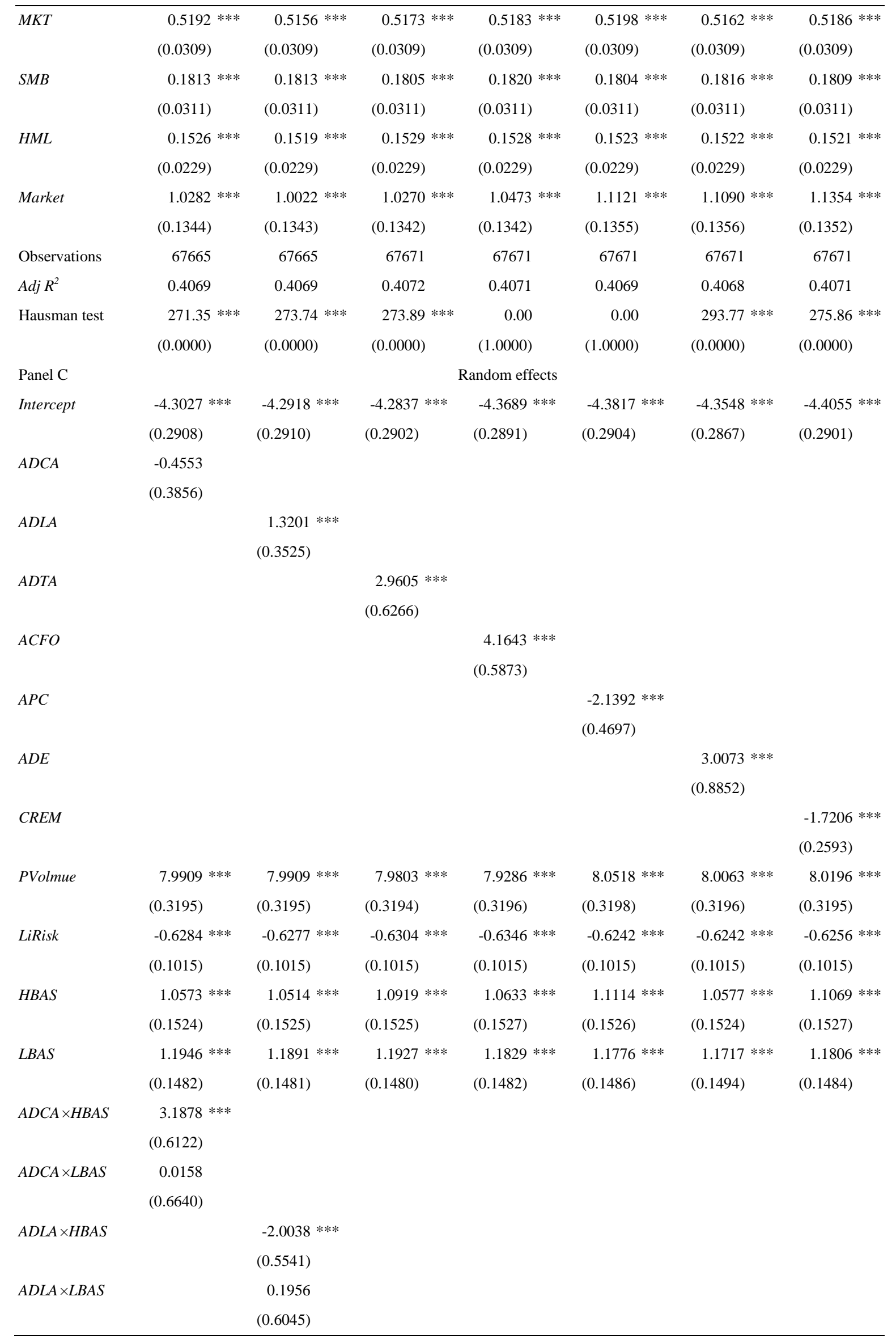




\begin{tabular}{|c|c|c|c|c|c|c|c|}
\hline \multirow[t]{2}{*}{$A T D A \times H B A S$} & & & 0.5643 & & & & \\
\hline & & & $(0.9032)$ & & & & \\
\hline \multirow[t]{2}{*}{$A T D A \times L B A S$} & & & 0.0282 & & & & \\
\hline & & & (1.0078) & & & & \\
\hline \multirow[t]{2}{*}{$A C F O \times H B A S$} & & & & $-4.7850 * * *$ & & & \\
\hline & & & & $(0.8096)$ & & & \\
\hline \multirow[t]{2}{*}{$A C F O \times L B A S$} & & & & $-2.2027 * *$ & & & \\
\hline & & & & $(0.9473)$ & & & \\
\hline \multirow[t]{2}{*}{$A P C \times H B A S$} & & & & & 0.1020 & & \\
\hline & & & & & $(0.6699)$ & & \\
\hline \multirow[t]{2}{*}{$A P C \times L B A S$} & & & & & $2.2401 * * *$ & & \\
\hline & & & & & $(0.7680)$ & & \\
\hline \multirow[t]{2}{*}{$A D E \times H B A S$} & & & & & & 2.0157 & \\
\hline & & & & & & $(1.5861)$ & \\
\hline \multirow[t]{2}{*}{$A D E \times L B A S$} & & & & & & $-2.5820 *$ & \\
\hline & & & & & & (1.4936) & \\
\hline \multirow[t]{2}{*}{$C R E M \times H B A S$} & & & & & & & $0.9190 * *$ \\
\hline & & & & & & & $(0.3864)$ \\
\hline \multirow[t]{2}{*}{$C R E M \times L B A S$} & & & & & & & $1.3057 * * *$ \\
\hline & & & & & & & $(0.4272)$ \\
\hline \multirow[t]{2}{*}{ PVolume $\times H B A S$} & $12.9388 * * *$ & $12.9453 * * *$ & 12.9166 *** & $13.0097 * * *$ & $12.8679 * * *$ & $12.9419 * * *$ & $12.8505 * * *$ \\
\hline & $(0.4927)$ & $(0.4928)$ & $(0.4926)$ & $(0.4931)$ & $(0.4931)$ & $(0.4931)$ & $(0.4928)$ \\
\hline \multirow[t]{2}{*}{ PVolume $\times L B A S$} & $-4.7343 * * *$ & $-4.7295 * * *$ & $-4.7217 * * *$ & $-4.6900 * * *$ & $-4.7900 * * *$ & $-4.7514 * * *$ & $-4.7687 * * *$ \\
\hline & $(0.4282)$ & $(0.4282)$ & $(0.4281)$ & $(0.4283)$ & $(0.4283)$ & $(0.4282)$ & $(0.4281)$ \\
\hline \multirow[t]{2}{*}{ LiRisk $\times H B A S$} & -0.0672 & -0.0661 & -0.0668 & -0.0592 & -0.0711 & -0.0748 & -0.0680 \\
\hline & $(0.1157)$ & $(0.1157)$ & $(0.1157)$ & $(0.1157)$ & $(0.1157)$ & $(0.1157)$ & $(0.1157)$ \\
\hline \multirow[t]{2}{*}{ LiRisk $\times L B A S$} & $-1.7733 * * *$ & $-1.7673 * * *$ & $-1.7450 * * *$ & $-1.7832 * * *$ & $-1.8045 * * *$ & $-1.7893 * * *$ & $-1.7908 * * *$ \\
\hline & $(0.2542)$ & $(0.2541)$ & $(0.2541)$ & $(0.2540)$ & $(0.2548)$ & $(0.2547)$ & $(0.2544)$ \\
\hline \multirow[t]{2}{*}{$M K T$} & $0.8916 * * *$ & $0.8900 * * *$ & $0.8917 * * *$ & $0.8950 * * *$ & $0.8933 * * *$ & $0.8988 * * *$ & $0.8931 * * *$ \\
\hline & $(0.0174)$ & $(0.0175)$ & $(0.0174)$ & $(0.0172)$ & $(0.0173)$ & $(0.0170)$ & $(0.0173)$ \\
\hline \multirow[t]{2}{*}{$S M B$} & $0.4503 * * *$ & $0.4514 * * *$ & $0.4508 * * *$ & $0.4539 * * *$ & $0.4502 * * *$ & $0.4572 * * *$ & $0.4513 * * *$ \\
\hline & $(0.0230)$ & $(0.0230)$ & $(0.0230)$ & $(0.0229)$ & $(0.0230)$ & $(0.0227)$ & $(0.0229)$ \\
\hline \multirow[t]{2}{*}{$H M L$} & $0.1346 * * *$ & $0.1338 * * *$ & $0.1347 * * *$ & $0.1351 * * *$ & $0.1344 * * *$ & $0.1348 * * *$ & $0.1342 * * *$ \\
\hline & $(0.0192)$ & $(0.0192)$ & $(0.0192)$ & $(0.0191)$ & $(0.0192)$ & $(0.0190)$ & $(0.0191)$ \\
\hline \multirow[t]{2}{*}{ Market } & $1.5725 * * *$ & $1.5486 * * *$ & $1.5729 * * *$ & $1.5954 * * *$ & $1.6602 * * *$ & $1.6656 * * *$ & $1.6832 * * *$ \\
\hline & $(0.1279)$ & $(0.1279)$ & $(0.1277)$ & $(0.1277)$ & $(0.1290)$ & $(0.1290)$ & $(0.1287)$ \\
\hline Observations & 67665 & 67665 & 67671 & 67671 & 67671 & 67671 & 67671 \\
\hline $\operatorname{Adj} R^{2}$ & 0.1034 & 0.1032 & 0.1041 & 0.1047 & 0.1039 & 0.1056 & 0.1041 \\
\hline
\end{tabular}

Note. $A R=$ abnormal return; $A D C A=$ abnormal discretionary current accruals; $A D L A=$ abnormal discretionary long-term accruals; $A T D A=$ abnormal total discretionary accruals; $A C F O=$ abnormal cash flow from operation; $A P C=$ abnormal production $\operatorname{costs} ; A D E=$ abnormal discretionary expenses; Volume $=$ monthly average trading volume; $P$ Volume $=$ monthly average trading amount; LiRisk= firm liquidity risk; MLiRisk =market liquidity risk; Liqui= firm liquidity; MLiqui= market liquidity; HBAS= the high level of information asymmetry; $L B A S=$ the low level of information asymmetry; $M K T=$ market premium factor; $S M B=$ size factor; $H M L=$ book-to-market factor; Market= market dummy. Standard errors are indicated in parentheses. *, **, *** denote statistical significance at the 10 percent, 5 percent and 1 percent levels (two-tailed), respectively. 


\section{Conclusions}

In this study, we investigate the impact of earnings quality and liquidity on cost of equity for listed firms in Taiwan from 2000 to 2011. The proxies of discretionary accruals are calculated by using abnormal discretionary current accruals, abnormal discretionary long-term accruals and abnormal total discretionary accruals. Under real earnings management, we apply cash flow from operation, production costs and discretionary expense as the indicators. We also apply individual liquidity risk and market liquidity risk as liquidity risk proxy. While liquidity indicators are estimated using stock trading volume, individual stock liquidity and market liquidity. The proxy of cost of equity uses the estimate of Fama-French three-factor model abnormal returns of stocks. The results show that three indicators of discretionary accruals are positively related to the cost of equity capital while the three real earnings indicators have the opposite effects on the cost of equity. Contrary to prior studies, trading volume and the cost of equity show a significant positive relationship while the negative relationship presented between individual stock liquidity risk and the cost of equity.

After taking the number of top and bottom quartile as the indicators of information asymmetry and applying earnings quality, trading volume and liquidity risk as interaction terms, the panel data regression analysis of long-term discretionary accruals or real earnings management show that the higher information asymmetry, the lower company's cost of equity when earnings quality deteriorates. Under higher asymmetric information, uninformed traders may fail to respond to the earnings management. In terms of trading volume and liquidity risk, if the liquidity and liquidity risk are high, the cost of equity is low when the degree of information asymmetry is low. This result confirms that managers need to fully disclose information to reduce the external cost of equity capital.

\section{References}

Aboody, D., Hughes, J., \& Liu, J. (2005). Earnings quality, insider trading, and cost of capital. Journal of Accounting Research, 43(5), 651-673. http://dx.doi.org/10.1111/j.1475-679X.2005.00185.x

Acharya, V. V., \& Pedersen, L. H. (2005). Asset pricing with liquidity risk. Journal of Financial Economics, 77, 375-410. http://dx.doi.org/10.1016/j.jfineco.2004.06.007

Attig, N., Fong, W. M., Gadhoum, Y., \& Lang, L. H. P. (2006). Effects of large shareholding on information asymmetry and stock liquidity. Journal of Banking \& Finance, 30, 2875-2892. http://dx.doi.org/10.1016/j.jbankfin.2005.12.002

Bhattacharya, N., Desai, H., \& Venkataraman, K. (2013). Does earnings quality affect information asymmetry? Evidence from trading costs. Contemporary Accounting Research, 30(2), 482-516. http://dx.doi.org/10.1111/j.1911-3846.2012.01161.x

Bhattacharya, N., Ecker, F., Olsson, P. M., \& Schipper, K. (2012). Direct and mediated associations among earnings quality, information asymmetry, and the cost of equity. The Accounting Review, 87(2), 449-482. http://dx.doi.org/10.2308/accr-10200

Botosan, C. (1997). Disclosure level and the cost of equity capital. The Accounting Review, 72(3), 323-349.

Botosan, C., \& Plumlee, M. (2002). A re-examination of disclosure level and the expected cost of equity capital. Journal of Accounting Research, 40(1), 21-40. http://dx.doi.org/10.1111/1475-679X.00037

Chae, J. (2005). Trading volume, information asymmetry, and timing information. The Journal of Finance, 60(1), 413-442. http://dx.doi.org/10.1111/j.1540-6261.2005.00734.x

Chordia, T., Subrahmanyam, A., \& Anshuman, V. R. (2001). Trading activity and expected stock returns. Journal of Financial Economics, 59(1), 3-32. http://dx.doi.org/10.1016/S0304-405X(00)00080-5

Davivongs, K., \& Pavabutr, P. (2012). Pricing of liquidity risk in emerging markets: Evidence from Greater China. International Review of Business Research Papers, 8(1), 20-32.

Dechow, P. M., Sloan, P., \& Sweeney, A. P. (1995). Detecting earnings management. The Accounting Review, 70(2), 193-225.

Deng, X., \& Ong, S. E. (2014). Real earnings management, liquidity and reits SEO dynamics. AREUEA-ASSA annual meeting, Philadelphia, PA, 3-5 January.

Fama, E. F., \& French, K. R. (1993). Common risk factors in the returns on stocks and bonds. Journal of Financial Economics, 33, 3-56. http://dx.doi.org/10.1016/0304-405X(93)90023-5

Francis, J., LaFond, R., Olsson, P., \& Schipper, K. (2004). Cost of equity and earnings attributes. The Accounting Review, 79(4), 967-1010. http://dx.doi.org/10.2308/accr.2004.79.4.967 
Francis, J., LaFond, R., Olsson, P., \& Schipper, K. (2005). The market pricing of accruals quality. Journal of Accounting and Economics, 39, 295-327. http://dx.doi.org/10.1016/j.jacceco.2004.06.003

Gray, P., Koh, P. S., \& Tong, Y. H. (2009). Accruals quality, information risk and cost of capital: Evidence from Australia. Journal of Business Finance \& Accounting, 36(1)\&(2), 51-72.

Kyle, A. S. (1985). Continuous auctions and insider trading. Econometrica, 53(6), 1315-1336. http://dx.doi.org/10.2307/1913210

Lee, K. H. (2011). The world price of liquidity risk. Journal of Financial Economics, 99(1), 136-161. http://dx.doi.org/10.1016/j.jfineco.2010.08.003

Pastor, L., \& Stambaugh, R. F. (2003). Liquidity risk and expected stock returns. Journal of Political Economy, 111, 642-685. http://dx.doi.org/10.1086/374184

Roychowdhury, S. (2006). Earnings management through real activities manipulation. Journal of Accounting and Economics, 42, 335-370. http://dx.doi.org/10.1016/j.jacceco.2006.01.002

\section{Copyrights}

Copyright for this article is retained by the author(s), with first publication rights granted to the journal.

This is an open-access article distributed under the terms and conditions of the Creative Commons Attribution license (http://creativecommons.org/licenses/by/3.0/). 